Historic, Archive Document

Do not assume content reflects current scientific knowledge, policies, or practices. 



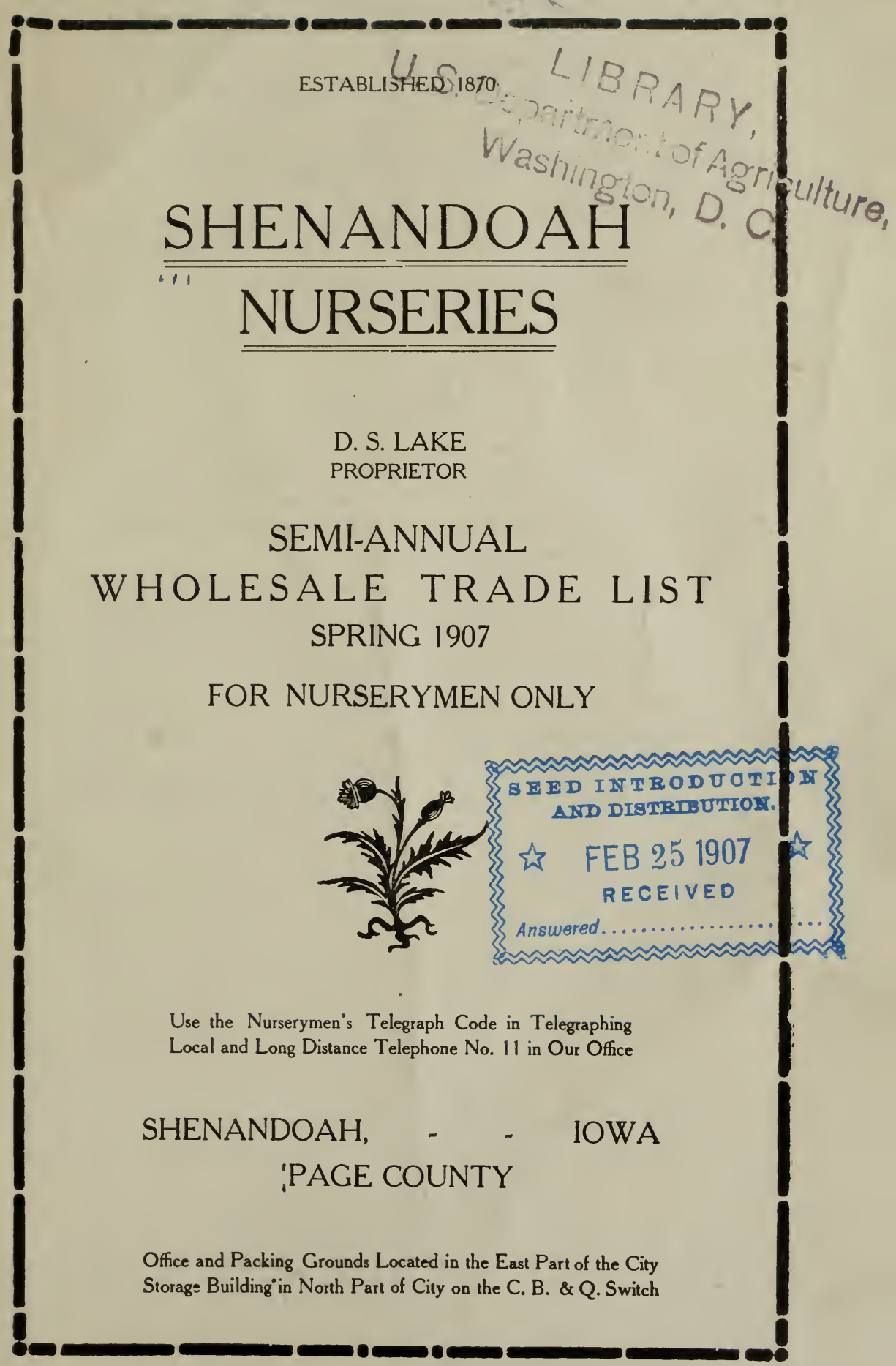




\section{For Your Information}

To those who are not acquainted with our concern, would say that this is the $37 \mathrm{th}$ year of our nursery. During this time, it has been under the same management as at present.

We are located in Southwestern Iowa, fifty miles from Ornaha, Nebraska. O 4 . soil here is specially adapted to the growing of a general line of Nursery Stock. Our railroad facilities are excellent. We are on the Wabash, Chicago, Burlington \& Quincy, Keokuk \& Western railroads, two express companies-Adams and Pacific-give us good service. We take pleasure in showing visitors over nur हrounds at any time.

\section{Jerms of Sale}

SHIPPING-Our shipping season in the Spring begins about March 20 tl. Parties' ordering goods should indicate whether they wish them sent by freight or express, also route. In the absence of these instructions, we forward them to the best of our judgment, but in no case will we assume responsibility after consignment to purchaser.

TERMS-Cash or security before shipment of goods, except with established firms, when, if unknown to us, satisfactory reference will be required before 'goods are forwarded. Orders to be sent C. O. D. should be accompanied by onefourth cash.

PRICES-Are limited to the Spring of 1907 and supersede all previous lists, and are subject to change without notice.

CAUTION-We accept all orders upon condition that they shall be void, should any injury befall stock from frost, fire, hail, storms or other eauses over which we have no control.

CLAIMS-For deduction will receive consideration only when made within six days after receipt of goods.

PACKING.-Prices contained herein are net; cost of boxing and baling will be added.

CERTIFICATE OF INSPEC'TION will be furnished with each shipment.

GUARANTEE OF GENUINENESS-While we exercise the greatest diligence and care to have our stock true to label, it is mutually agreed between ourselves and purchaser that our Guarantee of Genuineness shall in no case make us liable for any sum greater than that originally paid for stock that proves untrue.

\section{Boxing and Packing Charges}

$30 \times 36 \times 9$ feet $\ldots, \ldots, \ldots, \ldots$

$\$ 0 \times 30 \times 10$ feet $\ldots \ldots \ldots \ldots$

$\$ 3.25,24 \times 30 \times 9$ feet $\ldots \ldots \ldots \ldots$

$30 \times 30 \times 9$ feet ... ........

$3.2524 \times 24 \times 9$ feet ... ........

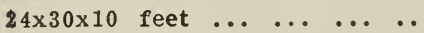

$3.0018 \times 18 \times 9$ feet $\ldots \ldots \ldots \ldots$

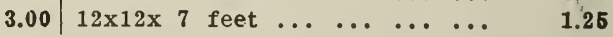




\section{Jruit Jrees, Small Jruits, Ete.}

\section{APPIES-General Assortment}

Growing a full assortment of well tested varieties of apple is one of our specialties. We feel sure they will please you both in quality and grade.

Code Pel 100 Per 1000 Standard, first-class, 5 feet and up 11-16 inch and up..... Fact $\$ 700 \$ 6500$

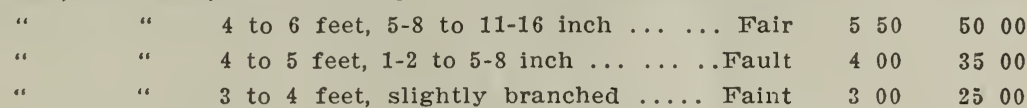

\section{Ieading Varieties}

\section{SUMMER}

* A. S. Pearmain

* Benoni

Chenango strawherry

*Duchess

* Fameuse or Snow Flora Belle Haas

* Ark. Beauty

Ark. Black

Baldwin

Ben Davis

* Banana

Carthouse

Cranberry Pippin

Coffelt

Day

Gano

Grimes Golden

Gideon's Best

* Harry Kaump

Huntsman

Iowa Blush
*Ea. Harvest
*Red Astrachan
*Fed June
Sumimer Pippin

FAII

*Hiberna?

M. Blush

Rambo

\section{WINTER}

*Iowa Beauty
Ingram
Janet
* Jonathan
King of T. Co.
Lansingburg
*I.ongfield
Lawver
*Malinda
M. B. Twig
McMahon's White
Mann Mippin
Mo. Pipping
N. W. Greening
*No. Spy
*Patten's Greening

Summer Fambo

Summer Queen

Sweet June

* Yellow Transparent

Red Beitigheimer

Utter's Red

Wealthy

Peerless
Pewaukee
Price's Sweet
Ramsdell Sweet
Roman Stem
Salome
Stayman's Wine Sap
Scott's Winter
Stark
Tal. Sweet
W. W. Pearmain
Walbridge
Wine Sap
*Wolf River
Yellow Belleflower
* York Imperial

Peerless

Pewauke

Ramsdell Sweet

Roman Stem

Stayman'g Wine Sap

Scott's Winter

Wine Sap

Yellow Belleflower

*York Imperial

Varletie marked with $2 *$ will be booked only in such proportion in assertment a our stock will permit. If supplied alone $\$ 10.00$ per $\mathbf{M}$ additionul.

\section{CZAI APPIES}

Standard, first-cleas, foet a d up, 11-16 inch and up .... Fear

s"

4 to feet, 5-8 to 11-16 inch ... ... Feel

8 to $11 / 4$ fot, $1-2$ te $5-8$ inch ... . . Fence

3 to 1 lot, vlightly branched ... .. Feat

Ireading Varieties

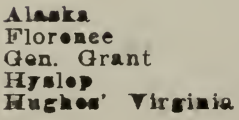

Lyman Prolific

Milton

Merthe

Q. C. Cluster

Red siberian
Soulard

Sylvan Sweot

Whitney

White Arctie

Y llow siberlas 


\section{PEARS}

Code Per 100 Per 1000

Stanclard, 5 feet and up, 3-4 inch and up ............. Fib $1600 \quad 15000$

4 to 5 feet, $5-8$ to $3-4$ inch ............. Fie $1300 \quad 12000$

\section{wea ung Varieties}

Beurre DeClairgeau

Clapps Favorite

Duchess

Flemish Beauty

mish Beauty Sheldon
Tyson

Ticar....

IVilder ... $\begin{array}{llll}11 & 00 & 100 & 00\end{array}$

$\begin{array}{llll}9 & 00 & 80 & 00\end{array}$

4 to 6 feet, $5-8$ to $3-4$ inch ... ... ..... Fill

$\begin{array}{llll}800 & 70 & 00\end{array}$

4 to 5 feet, $1-2$ to $5-8$ inch ......... Film

Dwarf, 2 year, first-class, $3-4$ inch and up .......... Flint

900

$7 \quad 50$

600

\section{Ieating Varieties}

Bartlett

Beurre D'Anjou

Clapps Favorite
Duchess D'Angoleme
Garbe:

Howell
Kieffer

I. Bonne

Seckle

\section{CFERTIES-Sour}

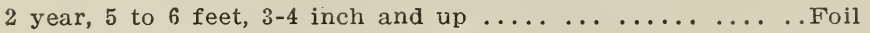

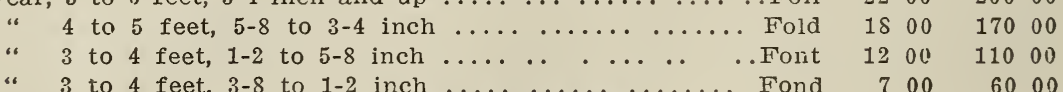

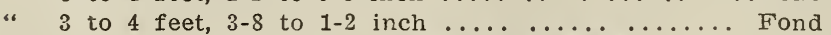

\section{Ieading Varieties}

Baldwin

Dyehouse

Eng. Morello
Olivet

Ostheimır

Wragg

1000

$\begin{array}{lll}7 & 0 & 0\end{array}$

500

\section{PEACEES}

First-class, one year, 5 to 6 feet, 11-16 inch and up .... Fuel

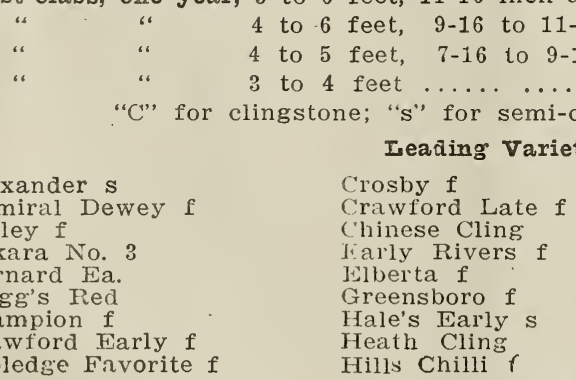

$\begin{array}{llll}6 & 00 & 50 & 00\end{array}$

$\begin{array}{lllll}5 & 00 & 45 & 00\end{array}$

\section{Ieađing Varieties}

Alexander s

Admiral Dewey $f$

Bailey $f$

Bokara No.

Barnard Ea

Brigg's Red

Crawford Early $f$

Cooledge Favorite $f$

\section{ARRICOTS}

Russian, 2 years, 5 to 6 feet, 11-16 inch and up . ..... Fund " " 4 to 5 feet, $5-8$ to $11-16$ inch .........Fur $31 / 2$ to $4 \frac{1}{2}$ feet, $1-2$ to $5-8$ inch ..... Fuse
Lemon Cling

O. M. Free $f$

O. M. Cling

sneed s

Salivay $f$

Stump r

Triumph f

Wright Seedling $f$

Wonderful $f$

\section{Ieading Varieties}

Alexander

J. L. Budd

Gibb

We have some nice seedling Apricot trees that we offer $2 \mathrm{c}$ per tree lower than the named sorts.

\section{QUINCI}

3 to 4 feet, $7-16$ to $9-16$ inch ........... Gypsy 1600

2 to 3 feet, $5-16$ to $7-16$ inch .......... Gyral 1300

\section{Ieading Varleties}

Champion

Meeches

Rea's 


\section{PIUMS}

Americana and Chickasaw on Plum.

Code Per 100 Per 1000

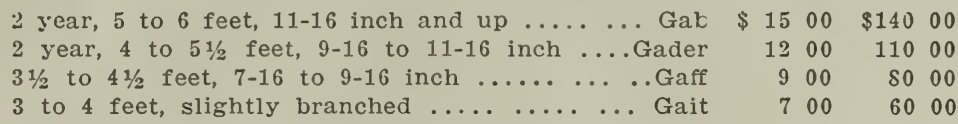

\section{Ieading Varieties}

Cheney

Chas. Downing

Desoto

Forest Garden

Hawkeye

Hammer
Milton
Pottawattamie
Quaker
Surprise

Hammer

Pottawattamie

Surprise
Stoddard

Wild Goose

Weaver

Wyant

Wolf

Miner in quantity $4 \mathrm{c}$ per tree less than the above varieties.

Americana on Peach.

2 years, 5 to 6 feet, $11-16$ and up ........ Gaunt

2 years, $41 / 2$ to 5 feet, $9-16$ to $11-16$ inch ...... Gave

2 years, $3 \frac{1}{2}$ to $4 \frac{1}{2}$ feet, $7-16$ to $9-16$ inch ... Gavel

2 years, 3 to 4 feet, slightly branched ... ... Gay

\section{reading Varieties}

Cheney
Desoto

F. Garden

- Pottawattamie

Wolf

Wild Goose

\section{European on Plum.}

2 year, 5 to 7 feet, 3-4 inch and up . .... Gallery

2 year, 4 to 6 feet, 5-8 to 3-4 inch ....... Gallon

2 year, 4 to 5 feet, $1-2$ to $5-8$ inch ........ Gabbler

\section{Ieading Varieties}

Beauty of Naples

Bradshaw

Guii

German Prune

Japanese on Flum.

2 year, 5 to 6 feet, $3-4$ inch and up ......... Gall

2 year, 4 to 6 feet, $5-8$ to $3-4$ inch ......... Gage

2 year, 4 to 5 feet, $1-2$ to $5-8$ inch ......... Gap

$\begin{array}{rrrr}11 & 00 & 100 & 00 \\ 9 & 00 & 80 & 00 \\ 7 & 00 & 60 & 00\end{array}$

\section{Ieading Varieties}

$\begin{array}{lll}\text { Abundance } & \text { Prunus Simoni } & \text { Satsuma } \\ \text { Burbank } & \text { Red June } & \text { Wickson }\end{array}$

\section{MUIBERRY}

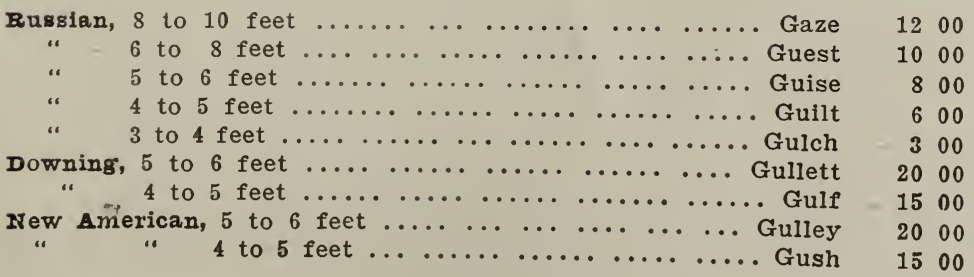




\section{GRAPE VINES}

Code Per 100 Per 1000

Agawan, (Roger's No. 15), Red 2 year ............ Hail $\$ 350 \$ 3000$

" " " " " 1 year ...........

$250 \quad 2000$

Erighton, Coppery Red, 2 year ............... Hare

$\begin{array}{llll}350 & 30 & 00\end{array}$

Concord, Black, 2 year $\ldots \ldots \ldots \ldots \ldots$. $\ldots \ldots \ldots \ldots$ Hard

$250 \quad 2000$

" " 1 year .................... Hark

$250 \quad 2000$

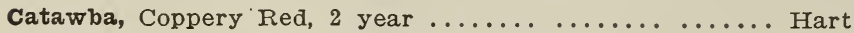

200

1500

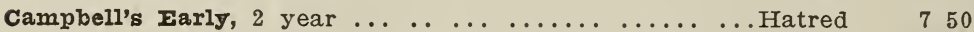

1 year $\ldots \ldots \ldots \ldots \ldots \ldots$.................... 600

Champion, Black, 2 year .................. Hazard 350

3503000

$250 \quad 2000$

Clinton, Black, 2 year ................................ 300

200

Delaware, Red, 2 year ................... Heed

Dracut, Amber, 1 year ................... Heft

350

Diamond (Moore's) White 2 year ...................

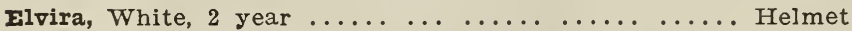

Empire state, white, 2 year ................. Hemp

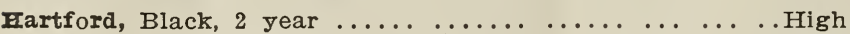

Ives Seediling, Black, 2 year ................ Hilt

Janesville, Black, 1 year .................. Hinge

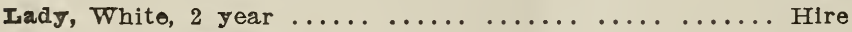

Iindley, (Roger' No. 9) 2 year ............... Hod

7.oore's grarls, Black, 2 year ................. Holst

arartha, White, g year ...................Holy

Jiagaran White, 2 year ................... Hone

Pooveltegtoa, Whito, 2 yoar .................. Hoot

Ialom, (Roger' No. 58), Coppory Red, 2 year ... ... Hostlle

Vorgonnea, Red, 2 year ................... Howl

" " 1 year .................. Hove

wordon, Black, z year ................... Hum

Wllder, (Roger' No. 1) Back, yoar .............Hurl

woodrux, rod, s year ................... Huek

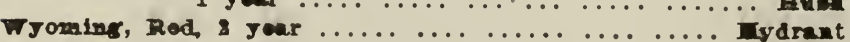




\section{CURRATTS}

Code Per 100 Per 1000

Black, General Assortment, 1 year No. 1 or 2 year No. 2.. Icy $\$ 200$

Black Naples

Black Champion
2 years No. 1 ............... Idem 300

Ieading Varleties Crandall

Lee's Prolific

Pomona, 1 year No. 1 or 2 years No. $2 \ldots \ldots \ldots$....... Induce 250

2 year No. $1 \ldots \ldots \ldots \ldots \ldots \ldots$................................ 350

Red, general assortment, 1 year No. 1 or 2 years No. 2 ..Idle 200

2 year No. 1 ............... Ignite 250

1600

Ieading Varletios

Cherry

Fay's Prolific

London Market

L. B. Holland

\section{La Versailles}

No. Star

Prince Albert
Red Dutch

Wilder

Victoria
Red Cross, 1 year No. 1 or 2 year No. $2 \ldots \ldots \ldots$....... Ignoble

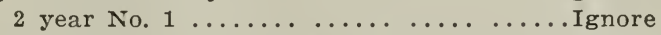

White Dutch, 1 year No. 1 or 2 years No. $2 \ldots \ldots \ldots$.... Impose

“ “ 2 years No. $1 \ldots \ldots \ldots \ldots$. ........... Impost

White Grape, 1 year No. 1 or 2 years No. $2 \ldots . . . .$. Instate

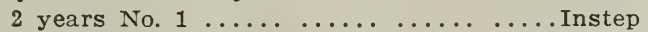

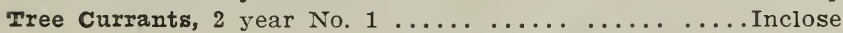

\section{GOOSEBIRZIES}

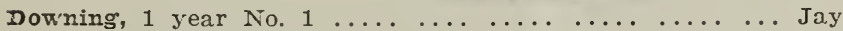

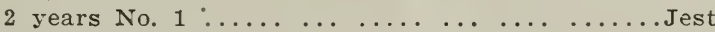

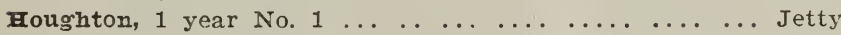

2 years No. $1 \ldots \ldots \ldots \ldots \ldots \ldots \ldots \ldots \ldots \ldots$

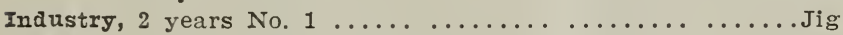

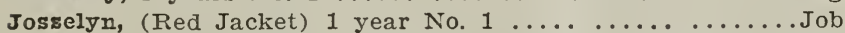

(Red Jacket) 2 years No. $1 \ldots \ldots \ldots$............

Fearl, 1 year, No. $1 \ldots \ldots \ldots \ldots$................ Joke

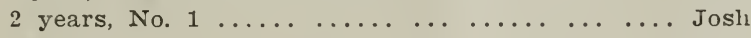

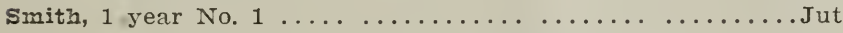

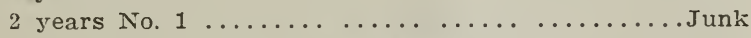

RASPBIEEIIS

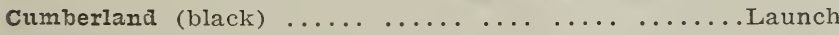

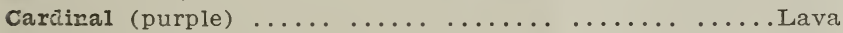

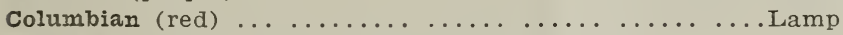

Cuthbert, Brandywine, Hansell, Miller's Red, and

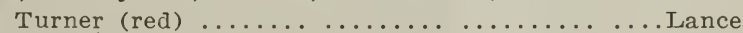

Golden Queen ......................... Lank

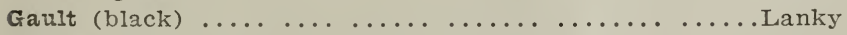

1000

Gregs, Kansas, Nemaha, Palmer, Ea. Ohio, Older,

Sougehan, Tyler, Eureka, and Lotta (black) ......Lace

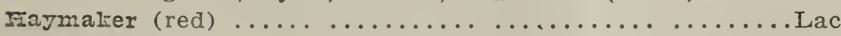

Iouden $($ red $) \ldots \ldots \ldots \ldots \ldots$. . . . . . . . . . . . . . . . . . . . .

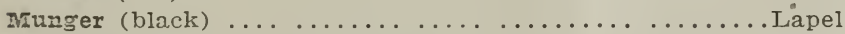

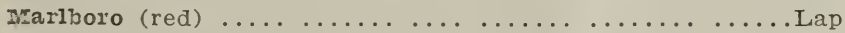

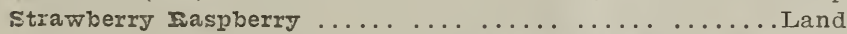

\section{EIACIREREIRS}

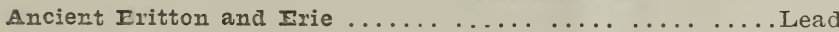

Ea. İarvest $\ldots \ldots \ldots \ldots \ldots \ldots \ldots \ldots \ldots \ldots$ Leap

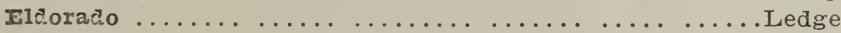

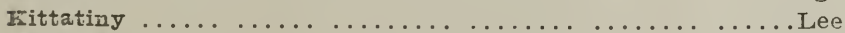

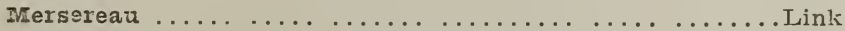

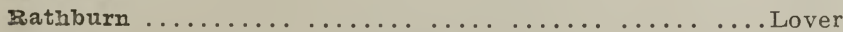

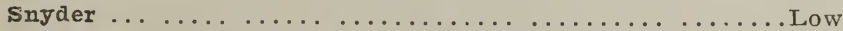

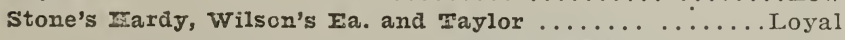

DEWBERIIES

Austin, Iucretia, and Premo
200

300

200

300

200

300

500

550

700

500

600

600

700

5 50

700

500

600

125

150

150

$10 \quad 00$

1200

1200

80

125

125

700

1800

2500

1800

2500

1800

2500

$90 \quad 00$

5500

6500

$10 \quad 00$ 


\section{STRAWBERRIES}

Ieading Varieties

\section{Bederwood}

Brandywine

Bubach

Crescent

G'andy

Glen Mary
Haverland
Jesse
Nick Ohmer
New York

Code Per 100 Per 1000

$$
\$ 35 \$ 300
$$

Rough Rider

Splendid

Senator Dunlap

Sample

Warfield

\section{GARDEN ROOTS}

Asparagus, Barr's Mammoth, 1 year ... ... ........ Lucre

$\begin{array}{rrrrr} & 40 & & 3 & 50 \\ 60 & & 4 & 50 \\ & 30 & & 3 & 50 \\ & 40 & & 3 & 50 \\ & 40 & & 3 & 50 \\ & 60 & & 4 & 50 \\ & 60 & & 30 & 50 \\ & 40 & & & \\ 60 & & 4 & 50 \\ 2 & 50 & 20 & 00 \\ 1 & 50 & 10 & 00\end{array}$

Rhubarb, Linneus, Vinegar Plant, strong roots ......... Lunge

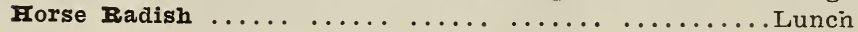

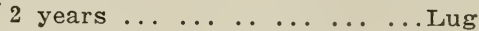

Conover's Colossal, 1 year ..................... . . . . . . " " 2 years ............ . . . . . . . . . . Columbian, 1 year ................. . . . . . . . . . . . . . . . .

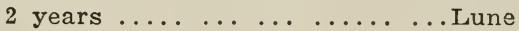
Palmetto, 1 year .................. Lung

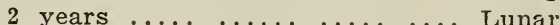

\section{MISCETIANHOUS}

Juneberry, Dwarf, 18 to 24 inches ................ Lurch

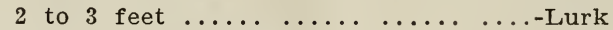

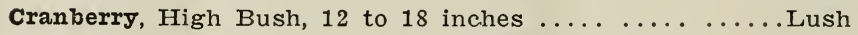

600

" " 18 to 24 inches ............... . . . .

800

“

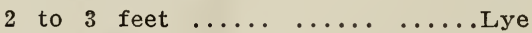

$10 \quad 00$

" " 3 to 4 feet ............... . .

1500

wineberry, ............................ . . . . . . . . . . . . . . . . . . . . . . . .

500

Ioganberry,

, $\ldots \ldots$

$\because \ldots \ldots \ldots \ldots$. $\ldots \ldots \ldots$ Lynch

500

\section{CUTIITGS}

Carolina, Iombardy and Aurea Poplar ..............

Golden, Ozier and Gray willow ...................

Wisconsin and Thurlow weeping willow .............

Tamarix, Amurensis

.......

..........

\section{ROOT GRAFTS}

We are now in the midst of making apple and other rootgrafts. Have a large force at work, and can handle orders promptly. Will use French roots where desired.

We would appreciate your graft order, and would be pleased to have list of wants for prices at any time. Samples sent on application, and all inquiries promptly answered.

Our grafting runs until April 20th. and your late orders will have prompt attention. Boxing free.

Code Per 100 Per 1000

Apple and Crab Grafts, Piece Root, 10,000 and up ................ 600

$$
\begin{aligned}
& 5,000 \text { and up to } 10,000 \ldots \ldots \ldots \ldots 6650 \\
& 1,000 \text { and up to } 5,000 \ldots \ldots \ldots \ldots 750
\end{aligned}
$$

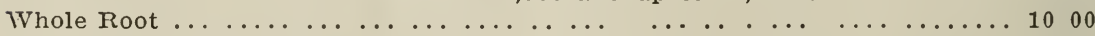

Pear Grafts, Piece Root ......................... . 800

" " Whole Root ......................... 1000

Plum Grafts, Piece Root .................. 800

Whole Root .............................. 1000

Place order for grafts early while the assortment of scions is complete. Special price on large orders. 


\section{FRUIT TREE STOCKS (American GrUTn)}

APPLE SEEDLINGS-We are sold very closely on all grades of "American Grown" apple seedlings. Can quote some of all grades upon application until stock is exliausted.

Will have a good supply of French Grown to offer in the grades as specified below under Imported Stocks. Will be oleased to mail samples and make prices. Frerch Apple Seedlings are noted for their vitality.

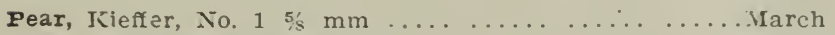

Code Per 100 Per 1000

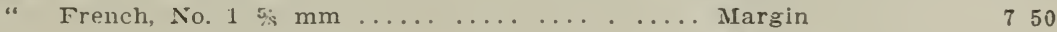

“. " No. $32-3 \mathrm{~mm} \ldots \ldots \ldots \ldots \ldots \ldots \ldots$................. 300

\section{FRUIT TREE STOCKS (French Grown) IMPORTED}

() ur supply of Imported Fruit Tree Stocks will be large and grades liberal. We have our representative in France, who buys direct from the small farmers and personally looks after the handling and packing of all stccks. Upon arrival in tlins country all boxes are unpacked and seedlings regraded, so customers will surely be well pleased. application.

APPLE SEEDLINGS-Can supply following grades. Prices made upon

No. 1, 3-16 inch and up, straight or branchetl.

No. 2, 2-16 to $3-16$, straight or branched.

No. 3, straight or branched

Cherry, Mahaleb, No. 1,5 to $8 \mathrm{~mm} \ldots \ldots \ldots \ldots \ldots$ Mass

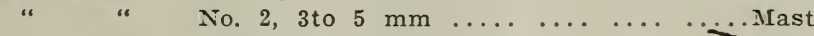

1000

500

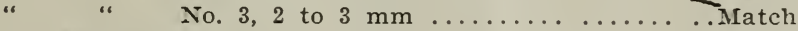

300

Mazzard, No. 1, 5 to $\& \mathrm{~mm}$............... Mayor

“ "No. 2,3 to $5 \mathrm{~mm} \ldots \ldots \ldots \ldots \ldots \ldots \ldots \ldots$.................. 700

1000

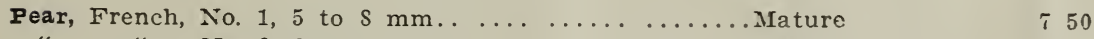

“ “No. 2, 3 to $5 \mathrm{~mm} \ldots \ldots \ldots \ldots \ldots \ldots$ Maud $\ldots \ldots$

“ "No. 3,2 to $3 \mathrm{~mm} \ldots \ldots \ldots \ldots \ldots \ldots \ldots$.............. 350

Plum, Myrobolan, No. 1,5 to $8 \mathrm{~mm} \ldots \ldots \ldots \ldots$ Maxim $\quad \mathrm{S} 50$

" "No. 2,3 to $5 \mathrm{~mm} \ldots \ldots \ldots \ldots \ldots \ldots$. Naybe 600

No. 3 , to $3 \mathrm{~mm} \ldots \ldots \ldots \ldots \ldots \ldots$............ 400

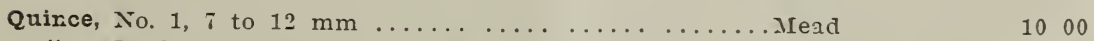

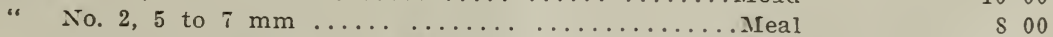

A charge of $(10)$ cents per $M$ will he made for pacling No. 1 and (5) cents ver II for packing No. 2.

ROSE STOCKS

Code

Per 1000

Manetti, Nio. 1, 5 to $8 \mathrm{~mm} \ldots \ldots \ldots \ldots \ldots \ldots \ldots$ Mean

Niultiflora, No. 1,5 to $8 \mathrm{~mm} \ldots \ldots \ldots \ldots \ldots \ldots \ldots \ldots \ldots \ldots$. . . . . . . . . . .

1000

1000

\section{HEDGE PIANTS}

Barberry, Purple Leaved, 6 to 12 inches ............. Mryiad

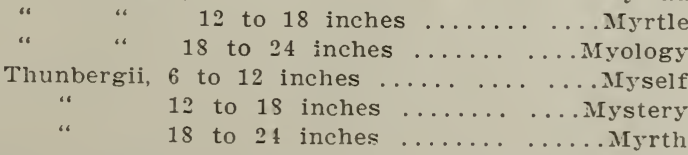

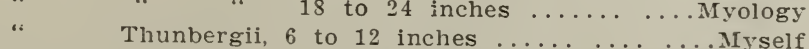

" " 18 to 24 inches ............... 
FOREST TREE SEEDLING⿺

Asi......................... Code

Per 1000

$\$ 125$

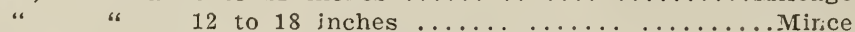

200

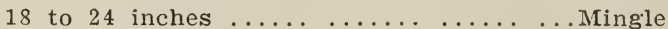

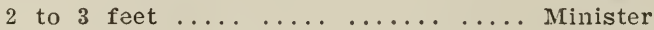

300

500

3 to 4 feet .................... Mink

Eoz Elder, 4 to 6 inches ...................... Mind

600

125

6 to 12 inches ...................... Mine

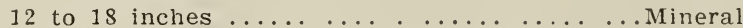

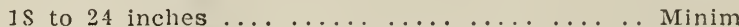

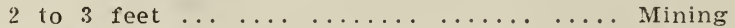

3 to 4 feet $\ldots \ldots \ldots \ldots \ldots \ldots \ldots \ldots$ Minion

Catalpa, 6 to 12 inches ..................... Mowing

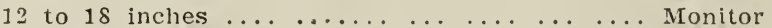

$\mathrm{E} 1 \mathrm{~m}, 6$ to 12 inches ....................... Monn

" 12 to 18 inches ...................... Moreen

. Is to 24 inches ....................... Morn

. 2 to 3 feet $\ldots \ldots \ldots \ldots \ldots \ldots \ldots \ldots \ldots$ Morning

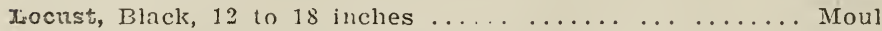

18 to 24 inches ................. Mucus

2 to 3 feet .................... Muff

3 to 4 feet $\ldots \ldots \ldots \ldots \ldots \ldots \ldots$ Muffin

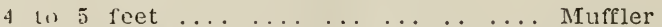

Honey, 4 to 6 inches ................. Muffle

6 to 12 inches .................. MIug

12 to 15 inches................. Muddy

Maple, Silver Leaved, soft or white, 6 to 12 inches .... Muster

" " " " " " " 12 to 18 inches.... Musty

is to 24 inches..... Nute

2 to :3 feet ...... Mutton

3 to 4 feet ....... Mruzzle

4 tu 5 feet .... Mutilute

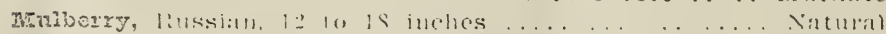

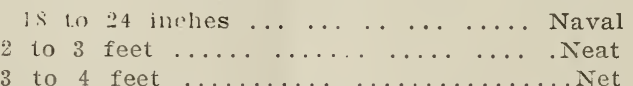

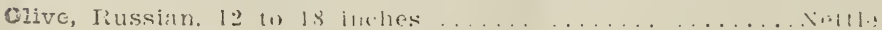

150

$\therefore 50$

400

500

70

175

250

175

$\therefore 50$

$\therefore 50$

500

250

$\therefore 00$

400

f 00

]1) 00

175

250

300

150

$\geq 70$

$\therefore \quad 50$

100

fi 00

$S 00$

:3 010

400

600

800

$\therefore \quad 10$

WIEEING TลีEES

Eirch, Cut Leaved, 3 to 4 reet ................ Neptune

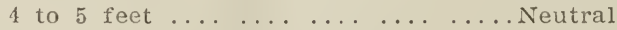

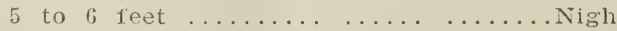

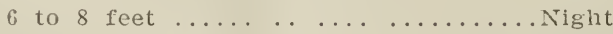

Elm, Camperdown, 1 yent heads .............. Noble

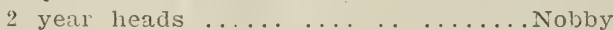

Int. Ash, Weeping, 1 year heads ................ . . . . . . . . . . . . . . . . . . . .

2 year heads .................. . . . . . . . . . . . . . . . . . . .

Jach Ser 10

30200

$35 \quad 2 \quad 50$

$40 \quad 300$

$50 \quad 400$

$40 \quad 300$

$50 \quad 4 \quad 00$

$30 \quad 2 \quad 00$

$35 \quad 250$

$14 \quad 125$

$17 \quad 150$

40300

$50 \quad 4 \quad 00$

14125

$17 \quad 150$

$13 \quad 120$

$16 \quad 150$

$\begin{array}{ccccccc}\text { Teas, Weejing Russian MIulberry, } 1 \text { year heads ..... . Nought } & 60 & 500 \\ \text { “ “ } & \text { “ } & 2 \text { year heads . . . . . Notice } & 75 & 650\end{array}$ 


\section{DECIDUOUS ORNAMENTAT TREES}

We have a good stock of Nursery Grown shade and ornamental trees. They have been twice transplanted, and are suitable for street and park planting.

Ash, American White, transplanted, 4 to 5 feet .......... Noun $\quad 60 \quad 500$

" " " " $" 5$ to 6 feet ........ Novel

6 to 8 feet ......... Novice

8 to 10 feet .......... Now

“. 10 to 12 feet, $1 \frac{1}{2}$ to 2 inch stem. . Nowise

. 90

800

“

$140 \quad 1200$

Birch, European, White, transplanted, 3 to 4 feet ........ Noon

$200 \quad 1800$

" " " " $" 4$ to 5 feet...... Nozzle

$2 \quad 25$

100

5 to 6 feet .......Nugget

120

150

$\begin{array}{lll}\text { " } & \text { " } \\ \text { ". } & \text { " } & \end{array}$

6 to 8 feet ......Nutting

8 to 10 feet ..... Nuptial

200

300

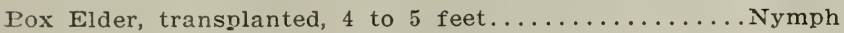

70

500

100

800

125

1000

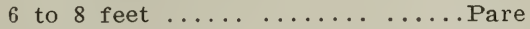

150

1250

220

2000

10 to 12 feet $1 \frac{1}{2}$ to 2 in. stem ......Pad

2 to $2 \frac{1}{2}$ inches ... ........ Padder

Butternut, transplanted, 3 to 4 feet .............. Pagan

400

100

3500

125

150

200

5 to 6 feet .......... Plantation

$\begin{array}{lll}2 & 0 & 0 \\ 2 & 5 & 0\end{array}$

Iuckeye,

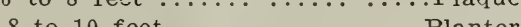

250

100

125

i 40

180

Catalpa, Iungei, 6 to 8 feet ................. Palette

4 to 5 feet ............... Patch

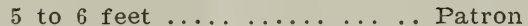

400

Transplanted, 4 to 5 feet ............... Paling

“ " $\quad 5$ to 6 feet .............. . Palish

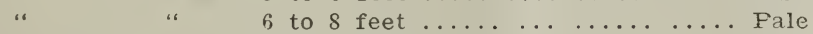

8 to 10 feet ............... Pall

Chestnut, Sweet, transplanted. 3 to 4 reet ........... Panel

70

600

130

800

160

1200

100

1500

150

800

175

1200

4 to 5 feet .............Panss

$\begin{array}{lll}1 & 75 \\ 2 & 0 & 0\end{array}$

1500

$\begin{array}{lll}2 & 00 \\ 2 & 50\end{array}$

Horse,

6 to 8 feet $\ldots \ldots \ldots$....... Paper

350

400

110

1000

Elm, American, transplanted, 4 to 5 feet ..........Parlow

180

1500

5 10 6 feet .......... Parole

6 to 8 feet ........... Parrot

250

300

20 0i

8 to 10 feet ......... Passion

10 to 12 feet, $1 \frac{1 / 2}{2}$ to 2 in. stem .... Passport

IEackberry. transplanted, 4 to 5 feet ............. Past

350

2500

100

3000

120

800

Jutas Tree, or Red Bud, 4 to 5 feet ............. Pawn

125

" " " $" \quad 5$ to 6 feet ............ Peal

150

6 to 8 feet . ............ Pedal

Iocust, Black, 4 to 5 feet ...................Peth

5 to 6 feet $\ldots \ldots \ldots \ldots \ldots \ldots \ldots$ Perch

8 to 10 feet, 1 to $1 \frac{1}{2}$ in. stems ....... Perish 125

10 to 12 feet $1 \frac{1 / 2}{20} 2$ in. stems ... ...Perjure 150

Horiey, 4 to 5 feet .................. . . . . . . . . . 1 jo

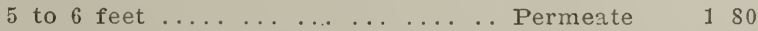

1000

Jarcli, 18 to 24 inches .................... Perk

1 SO

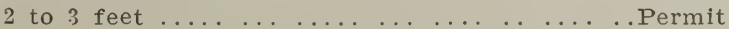

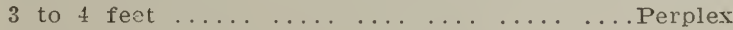




\section{DECIDUOUS ORNAMENTAL TRESS (Continued).}

Iinden, American, 3 to 4 feet ........................... I 00

4 to 5 feet $\ldots \ldots \ldots \ldots \ldots$.............. 125

5 to 6 feet ... ............ . . . . . . 175

Iinden, European, 4 to 5 feet ............... Pertain 150

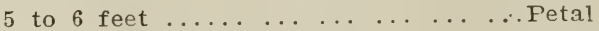

$\div 75^{\circ}$

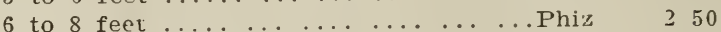

100

150

๖े 00

Mountain Ash. European, 4 to 5 feet ............. Picket

175

1200

6 to 8 feet .........................

150

1500

“ Oak Leaved, 4 to 5 feet ............. Place

Maple. Sil. Lvd., soft or white, transp., 4 to 5 feet ... . Plague

200

1250

$60 \quad 500$

$\begin{array}{llll}80 & 7 & 00\end{array}$

$120 \quad 1000$

5 to 6 feet $\ldots . .$. Pile

150

1250

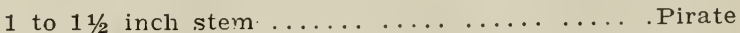

Sil. Lvd., soft cr white, transp. 10 to 12 feet ........

$11 / 2$ to 2 inch stem ................. Piston

$200 \quad 1800$

Sil. Lvd., soft or white transp., 10 to 12 feet $\ldots . .$.

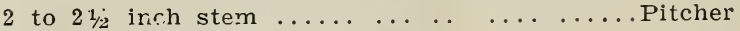

3000

Sugar, transplanted, 4 to 5 feet ..............Pier

i 50

175

5 to 6 feet ........... Pith

250

2200

8 to 10 feet 1 to $1 \frac{1 / 2}{2}$ in. ... Plan

300

10 to 12 feet $1 \frac{1}{2}$ to 2 in. Plank 500

Norway, transplanted, 5 to 6 feet ... ........ . Plan'

i) 20

250

400

500

8 to 10 feet, 1 to $1 \frac{1 / 2}{2}$ inch Poise 10 to 12 feet $1 \frac{1 / 2}{2}$ to 2 inch. Poetic

Weir's cut-leaved-transplanted 4 to 5 feet ......Polar

120

180

1000

" 5 to 6 feet ......Pole

200

1250

" 6 to 8 feet ....Popish

250

1500

inch stem ...................................

Weir's cut-leaved transplanted 10 to 12 feet $1 \frac{1 / 2}{2}$ to 2

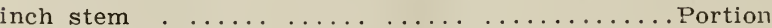

Olive, Russian, 3 to 4 feet $\ldots \ldots \ldots \ldots \ldots \ldots \ldots$ Part

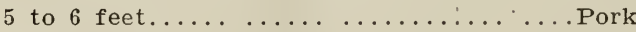

6 to 8 feet $\ldots \ldots \ldots \ldots \ldots \ldots \ldots \ldots$. . . . . . . . . .

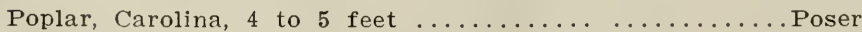

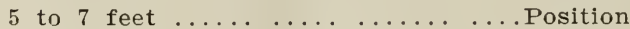

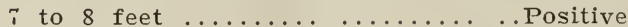

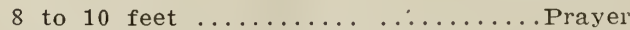

10 to 12 feet, 1 to $1 \frac{1}{2}$ inch stems ....Praise

12 to 14 feet, $11 / 2$ to 2 inch stem......Prance

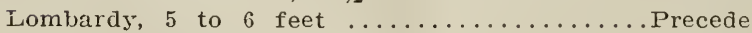

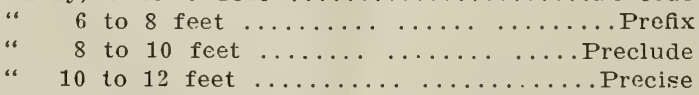

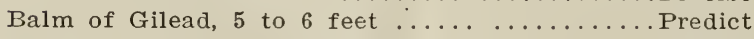

2000

350

$30 \quad 00$

1200

1500

50

60

100

125

600

150

200

100

125

150

175

100

125

125

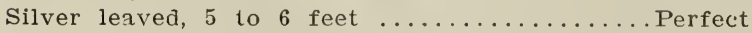

$\begin{array}{lll}1 & 25 \\ 1 & 50\end{array}$

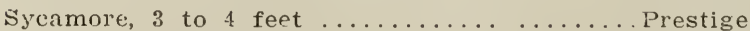

5 to 6 feet $\ldots \ldots \ldots \ldots \ldots \ldots \ldots$. . . . . .

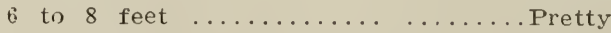




\section{DECIDUOUS ORNAMENTAI TREES (Continued)}

Code Per 10 Per 100

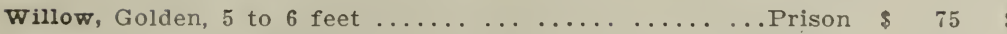

5 to $s$ feet $\ldots \ldots \ldots \ldots \ldots$. . . . . . . 100

Walnut, Black, 5 to 6 feet .............................. 150

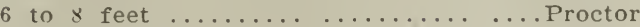

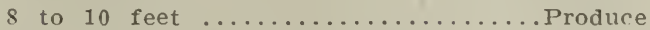

10 to 12 feet $1 \frac{1 / 2}{2}$ to 2 in. stems ........... Profile

Willow, Laurel Leaved, 4 to 5 feet ................. Prong

\section{ORNAMENTAI SHRUBS}

Almonds, dbl. flowering, pink and white, 12 to 18 inches Proper

Earberry, purple leaved, 6 to 12 inches .....................

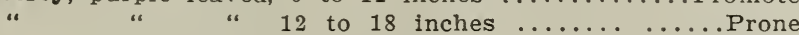
Thunbergi, 6 to 12 inches ................Pronoun

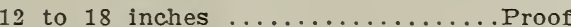

Crabs, Bechtel's double flowering, 2 to 3 feet ........... Propel " " " " $" 3$ to 4 feet.........Prosper 4 to 5 feet ...........Prose

Calycanthus, sweet scented shrubs, 12 to 18 inches.. Prostrate " " " "

" 2 to 3 feet .........Pullett

Cornus Sanguinea, red and white dog wood, 18 to $24 \mathrm{in}$. . Pulse

" " " 2 to 3 feet.Punch

$$
\text { " } 2 \text { to } 3 \text { feet. Punch }
$$

Deutzia, assorted hinds, 12 to 18 inches ....................

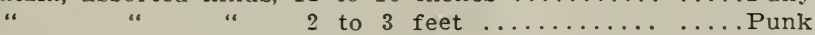

3 to 4 feet ................. Pumice

Elder, golden leaved, beautiful foliage, 18 to 24 inches ..Pump Iuonymus, strawberry tree, 4 to 5 feet ...............

$$
\text { " } 5 \text { to } 6 \text { feet } \ldots \ldots \ldots \ldots \ldots \text {........... }
$$

6 to 8 feet $\ldots \ldots \ldots \ldots$.......... Pursuit

Eleangnus, 12 to 18 inches $\ldots \ldots \ldots \ldots \ldots \ldots \ldots \ldots$ Purvey Fringe, purple or smoke tree, 3 to 4 feet.................

$$
\text { " } 4 \text { to } 5 \text { feet .................... }
$$$$
5 \text { to } 6 \text { feet .............Purity }
$$

Forsythia, Virdis Golden Bell ..........................

Honeysuckle, Tartarian, red, pink and white,

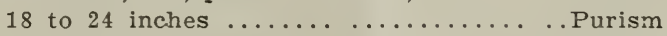

Tartarian, red, pink and white

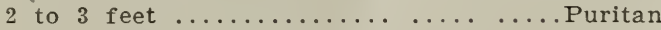

Tartarian, red pink and white

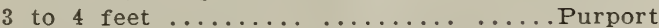

Hydrangea, Paniculata, Grandiflora, 12 to 18 inches .....Purl

$$
\text { " " " } 18 \text { to } 24 \text { inches ...Purple }
$$

$$
2 \text { to } 3 \text { feet ....Purpose }
$$$$
3 \text { to } 4 \text { feet .......Pus }
$$

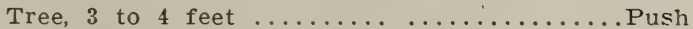

$$
\text { " } 4 \text { to } 5 \text { feet } \ldots \ldots \ldots \ldots \ldots \ldots \ldots \ldots \text {. . . . . . . . }
$$$$
\text { Cordata, } 2 \text { to } 3 \text { feet } \ldots \ldots \ldots \ldots \ldots \ldots \ldots \ldots \text {. . . . . . . }
$$

$$
3 \text { to } 4 \text { feet } \ldots \ldots \ldots \ldots \ldots \ldots \text {................ }
$$

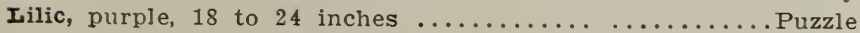

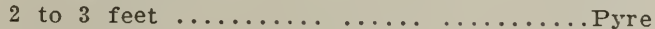

3 to 4 feet ..........................
175

200

250

350

100

125

100

125

150

180

100

125

100

1200

1500

1800

800

1000

300

400

300

600

175

1500

2000

2500

600

800

1000

600

800

1000

600

800

125

100

125

150

200

100

120

130

150

100 


\section{ORNAMENTAI SHEUBS (Continued)}

Code Per 10 Per 100

I.ilac, white, 18 to 24 inches ................. Raffle

$\$ 75 \$ 700$

2 to 3 feet $\ldots \ldots \ldots \ldots \ldots \ldots$. . . . . . . . . . .

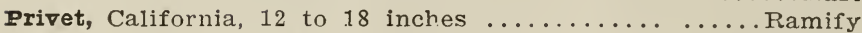

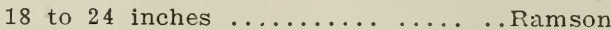

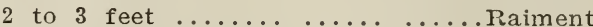

Quince, Japan Scarlet, 12 to 18 inches .............Rapture

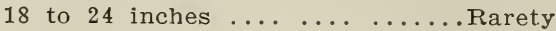

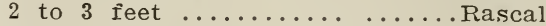

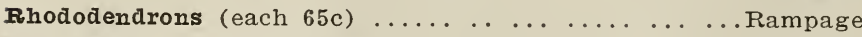

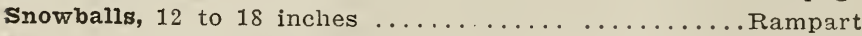

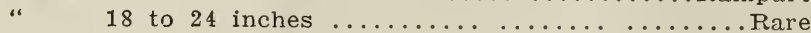

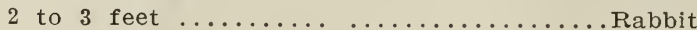

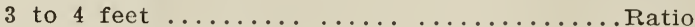

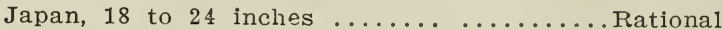

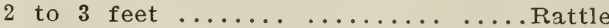

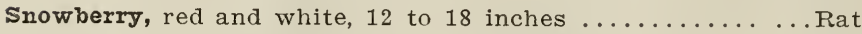

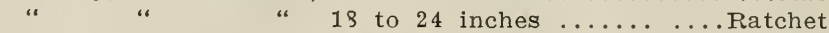

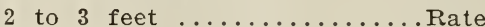

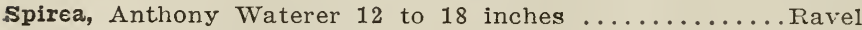

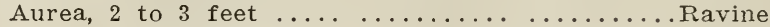

3 to 4 feet $\ldots \ldots \ldots \ldots \ldots \ldots \ldots$ Raw

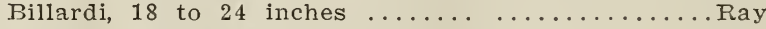

2 to 3 feet $\ldots \ldots \ldots \ldots \ldots \ldots \ldots \ldots \ldots \ldots \ldots \ldots$ Raze

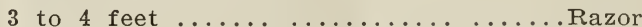

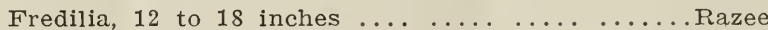

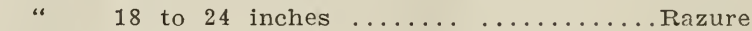

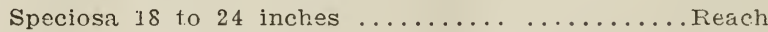

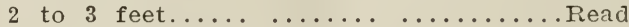

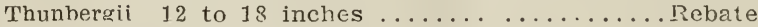

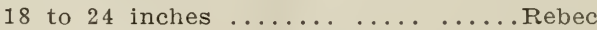

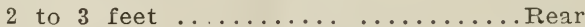

Van Houtti and Rosea, 12 to 18 inches...........Ration

" " 18 to 24 inches......Ratten

2 to 3 feet ..........Ravage

3 to 4 feet ............ Fave

Syringa, Mock Orange, assorted, 18 to 24 inches .......Rebel

" " " " 2 to 3 feet ..........Rebuke

3 to 4 feet ........ Recall

Tamariz Amurensis, 3 to 4 feet.................. Recast

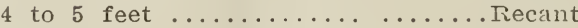

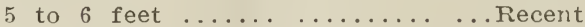

$$
\begin{aligned}
& 6 \text { to } 8 \text { feet ................ Receive }
\end{aligned}
$$

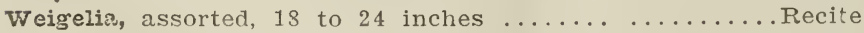

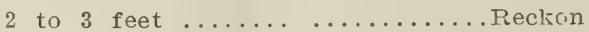

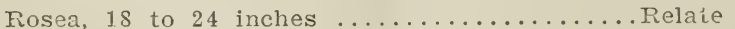

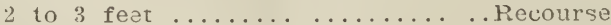

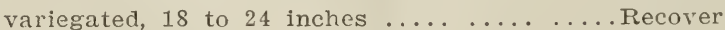

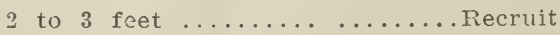

\section{VINES AND CITERPERS}

Arebia Crirata .........................Rector

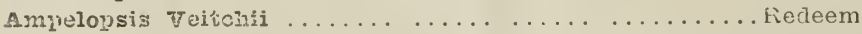

Engelmanii . . ... ... ......... Refine

Virginia Creeper or American Ivy ....... Refrain

Bignonia Radicans, Trumpet Creeper ............Refresh Celastrus, or Staff Tree, Bitter Sweet .............Refer Clematis, Cuccinea, bright scarlet ... ......... Reference

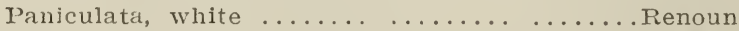

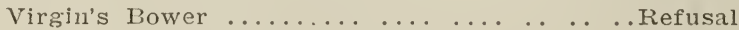

Viticella, purple or blue .......................
$110 \quad 1000$

25200

$30 \quad 250$

$40 \quad 350$

$50 \quad 400$

$\begin{array}{lll}70 & 6 & 00\end{array}$

90 \& 00

500

75

100

600

125

800

1000

$150 \quad 1200$

150

200

50

70

100

100

120

150

100

120

150

100

$1 \approx 0$

100

120

so

90

100

60

70

90

110

SO

100

125

9 (j)

110

130

160

100

120

100

120

120

140

600

800

800

$10 \quad 00$

1200

800

1000

1200

800

1000

800

1000

600

800

1200

400

600

800

1000

600

800

1000

800

1000

1200

1500

$S 00$

1005

800

$10 \quad 00$

$10 \quad 00$

1200

$120 \quad 1000$

$100 \quad 800$

$125 \quad 1000$

so 600

100 S $0 u$

100

$130 \quad 1200$

100 \& 00

$60 \quad 500$

$100 \quad \delta 00$ 


\section{VINES AND CREEPERS (Continued)}

Code Per 10 Per 100

Jackmanii, purple..................... . . . .

Duchess of Edinburg, Gypsy Queen, Henryil, Mad.

Baron Villard, Mad. Edward Anäre, Romona.Rampant

Honeysuckle, yellow and scarlet trumpet ...........Relay

$160 \quad 1500$

$125 \quad 1000$

Halleana; Chinese variegated and Golden leaf Relic $\quad 85 \quad 800$

Matrimony vines ......................... Ridge

100

Periploca; Virginia silk Vine..................Rivel

Wisteria Americana; purple flower .............. Roam

100

$85 \quad 800$

white $\ldots \ldots \ldots \ldots \ldots$........... Royal

$200 \quad 1500$

\section{EVERGREENS (Transplanted)}

We call attention to a complete stock of hardy western grown Evergreens. All orders are dug same day as shipped; and great care is used to keep the roots from exposure.

Arbor Vitae, American, 4 to 6 inches .................. . .

6 to 12 inches ................................

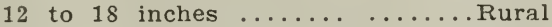

Balsam Iir, 6 to 12 inches ................. Saturate

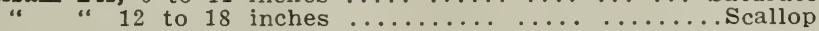

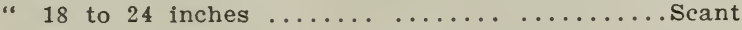

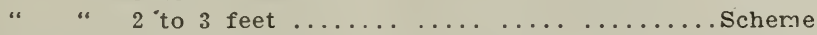

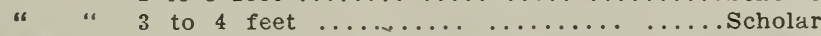

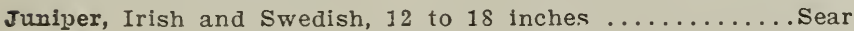

\begin{tabular}{|c|c|c|c|}
\hline & 30 & 2 & 00 \\
\hline & 40 & 3 & 00 \\
\hline & 60 & 5 & 00 \\
\hline & 90 & 7 & \\
\hline 1 & 00 & 8 & 0 \\
\hline 1 & 25 & 10 & 00 \\
\hline 1 & 50 & 12 & 50 \\
\hline 1 & 75 & 15 & 0 \\
\hline 1 & 25 & & \\
\hline 1 & 50 & & \\
\hline 2 & 00 & & \\
\hline 2 & Do & & \\
\hline 2 & 50 & & \\
\hline & 80 & 6 & 00 \\
\hline 1 & 00 & 8 & 00 \\
\hline 1 & 25 & 10 & 00 \\
\hline 1 & 50 & 12 & 50 \\
\hline & 75 & 5 & 0 \\
\hline & 90 & 7 & 0 \\
\hline 1 & 00 & 8 & 00 \\
\hline 1 & 00 & 9 & 0 \\
\hline 1 & 25 & 10 & \\
\hline & 60 & 4 & 00 \\
\hline 1 & 00 & 8 & 00 \\
\hline 1 & 25 & 10 & 00 \\
\hline 1 & 50 & 12 & 00 \\
\hline & 80 & 5 & 0 \\
\hline 1 & 25 & 10 & \\
\hline 1 & 50 & 13 & 00 \\
\hline & 80 & 5 & $O B$ \\
\hline 1 & 00 & 8 & \\
\hline 2 & 25 & 20 & 00 \\
\hline 1 & 75 & 15 & 0 \\
\hline 2 & 25 & 20 & 00 \\
\hline 3 & 00 & 25 & 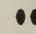 \\
\hline 1 & 50 & & \\
\hline 2 & 0 & & \\
\hline 2 & 50 & & \\
\hline 1 & $\begin{array}{l}00 \\
25\end{array}$ & & \\
\hline$i$ & 50 & & \\
\hline & i5 & 5 & \\
\hline & se & 6 & \\
\hline 1 & 25 & 10 & \\
\hline 1 & 50 & 18 & \\
\hline
\end{tabular}

Pine, Austrian, 6 to 12 inches

18 to 24 inches ............ Search

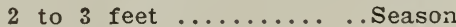

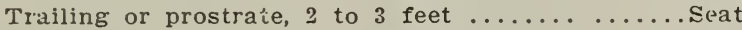

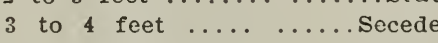

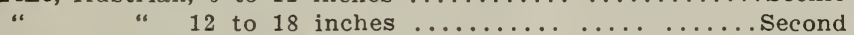

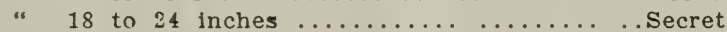

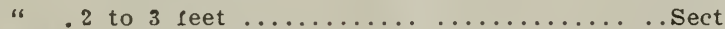

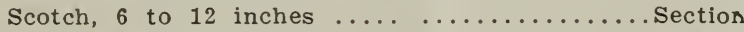

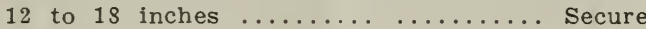

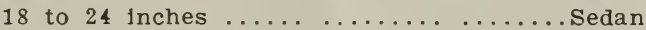

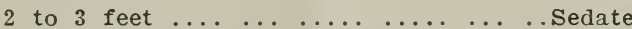

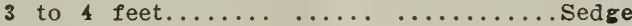

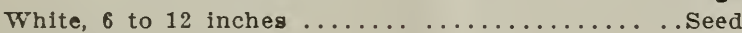

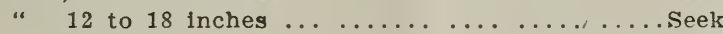

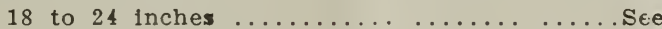

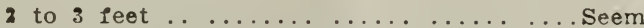

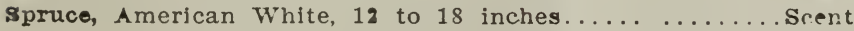

18 to 24 inches ......... Schisim

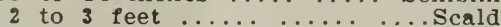

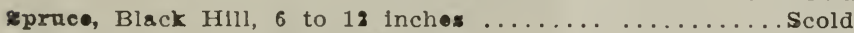

" " " 12 to 18 inchos .............. Scen

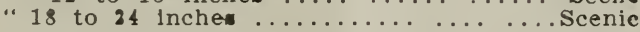

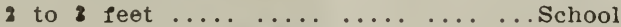

sprace, Colorado Blue, 6 to 18 inches ............. Scout

" 18 to 18 incho ............. Scow

Wraoe 18 to 84 inehe . ........... Scrap

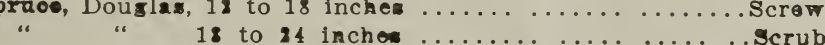

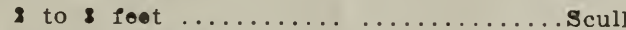

spruee, Femloek, 18 to 18 inche ................. Ses

18 to 24 inehe $\ldots \ldots \ldots \ldots \ldots \ldots \ldots \ldots$. . . . . . . . . . . . .

2 to 1 fect

Sean

Eprace, Norway, \& to 18 inches

Seamar

18 to 18 incter

Sor

18 to 84 inches $\ldots \ldots \ldots \ldots \ldots \ldots \ldots . \ldots \ldots$ senng

2 to 8 tout $\ldots \ldots \ldots \ldots \ldots \ldots \ldots$. . . . . . . 


\section{ROSES}

Code Per 10 Per 100 Eybria, perpetual, largely of the following kinds ...... Seine $\$ 110 \quad \$ 1000$

Alfred Colomb
Anna de Diesba.l
Baron de Ponstettin
Baron de Iothchild
Clip
Coq. de Alps
Coq. de Blanche
Dinsmore
Duke of Teck
Earl of Dufferin
Fisher Holmes

Alfred Colomb

Anna de Diesbar:]

Clip

Coq. de Blanche

Dinsmore

Earl of Dutferin

American Eeauty

General Waslington

General Jacqueminot

John Hopper

LaReine

Jubilee

Jules Margotten .. .

LaFrance

Meteor

Margaret Dickson

Mabel Morrison

Magna. Charta
Mad. Gabriel Juizet

M. P. Wilder

Mrs. Jno. Laing

M. G. Bruant

II. C. Woou

Paul Neyron

Paeonia

Prince Camille deRohan

Ulrich Brunner

Vintor Verdier

Vicks Caprice

Earrison's Yellow

Senate

150

Persian rellow

. Sieze

125

........... Seldom

125

Climbing; largely of following kinds ............ Select

Baltimore Belle

Empress of China

Prairie Queen

Climbing Victor Verd'r

Dorothy Perkins

Monthly, Madam Plantier, best hardy white ........... Self

Moss, leading kinds as follows: ......"

$\begin{array}{rrrr}90 & 8 & 00\end{array}$

Blanche Roberts
Blanche Moreau
Crimson Mos's

Henry jartin

Pink Moss

Princess Adelaide

Salet

White Moss

White Bath

Ramblers, Baby ... ....................... Selves

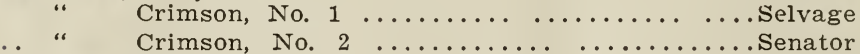

250

$100 \quad 800$

$\cdots$

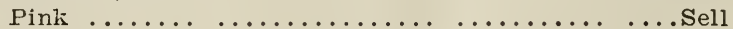

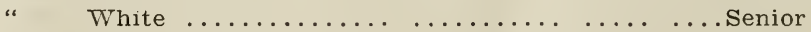

$100 \quad 800$

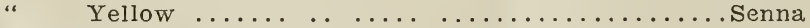

$100 \quad 800$

$100 \quad 800$

Wichurana Irybrids

100

S 00

Manda's 'Triumpli

Pink Foamer
Soutl Orange Perf. Universal Favorite

FEREACZOUS PAEONYES

Fink or Ieal, unnamed .................. Sentry

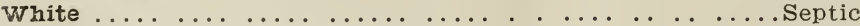

Fink or Red, named sorts ................... Surf

\section{SFFDS}

Apple French .........................per bu

Per tb. Per 10 ortos.

Ash

Box Flder

Catalpa

Iocust, black ................................. 20

" Honey ............................. 20

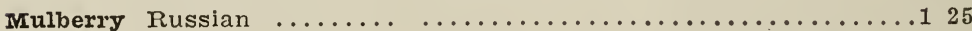

Peach Pits ............................... per bu 1.75 
IARDY IIERACEOUS FIOWERING PUANTS

Per Jo Per 100

Achillea, (The Pearl), white

Acquilegia, yellow or white $\ldots \ldots \ldots \ldots \ldots \ldots \ldots \ldots \ldots \ldots$

Dielytra spectabilis

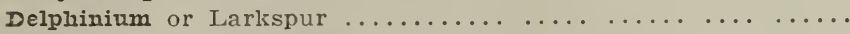

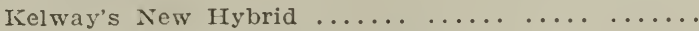

Chinensis, single, blue or white $\ldots \ldots \ldots \ldots \ldots \ldots$

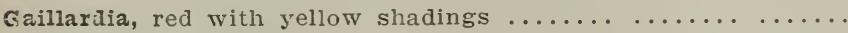

Gypsophitia Faniculata $\ldots \ldots \ldots \ldots \ldots \ldots \ldots \ldots \ldots \ldots$

Follyhocks, choice double $\ldots \ldots \ldots \ldots \ldots \ldots \ldots \ldots$

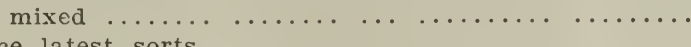

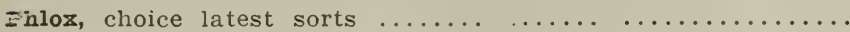

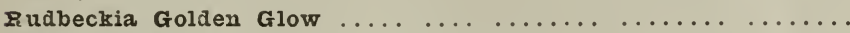

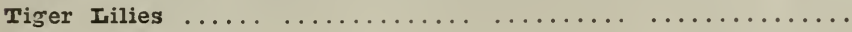

Yusca Filamentosa

\section{MISCEITANEOUS GREFNHOUSE FIANTS}

Asters, strong transplanted plants, white, lavender, pink, red

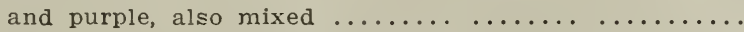

Carnations, strong 2 inch pots, pink, red, white, all named sorts

Chrysanthemums, strong, 2 inch in best named sorts either red,

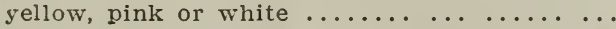

Geraniums, all named, either double or single any color, strong,

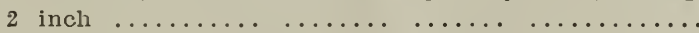

Ferns, hardy, for outdoor planting, two varieties ........

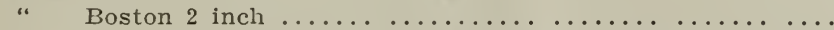

Asparagus Plumosus Nanus 2 inch ..............

Sprengeri $\ldots \ldots \ldots \ldots \ldots \ldots \ldots \ldots$

Eydrangea, (for house culture)

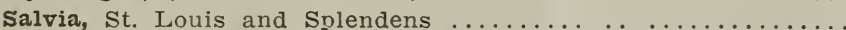

\section{IARDY BUIBS FOR FAII PIANTING}

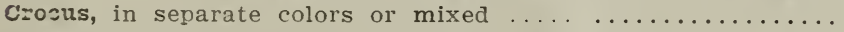

Frcesia, Refracta Alba, strong bulbs. ...............

Iyacinths, Dutch clouble or single in the following colors:

red, whit or blue .....................

Roman, white only

Iilium Candidum, white, very hardy blooms in June .......

Longifiorum, white trumpet ................ $120 \quad 10.00$

Narcissus (Daffodils) hardy, double ................ $\quad 50 \quad 350$

Tulips, single or double ......................... $30 \quad 200$

\section{TENDIE BUIBS AND TURERS FOR SPAING PIANTING}

Cannas, best standard named varieties $\ldots \ldots \ldots \ldots \ldots \ldots \ldots . \ldots \ldots$

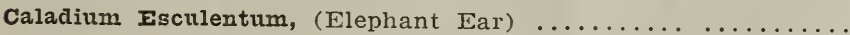

$$
\text { “ " " small size } \ldots \ldots \ldots \ldots \ldots
$$

Dahlias, choice double named sorts in the following colors:

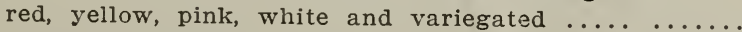

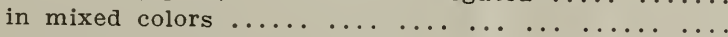

in separate colors, not named ................ $80 \quad 80 \quad 700$

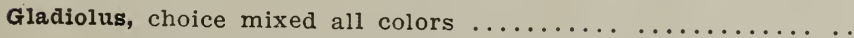




\section{NURSERYMEN'S SUPPIIES}

We always have on hand a complete line of Nurserymen's Supplies, which can be forwarded promptly on receipt of order.

\section{BOX STRAPS}

Made out of thin sheet steel and cut into strips, which average about nine inches long and one inch wide. It is very strong, tough and pliable, and holds the heaviest box. A nail can be driven through it readily without previous punching. Per pound .......

BURTAP

7 ounces to the yard, 40 incles wide. Per yard .............

\section{CARPFT WARP}

For tying buds; comes in skeins in packages of 5 lbs. each. Per

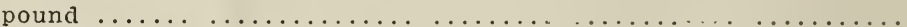

\section{CATAIOGUI DISCRIPTIVI}

Each

\section{COIIATING BOOKS}

To collate orders. Ruled with printed head lines, showing princi-

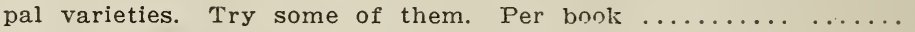

Per book, postpaid

\section{DEIIVIRY CASI EOOK}

Has ruled spaces for name of custoiner; amount if nriler. amount collected, etc.; holds 133 accounts. Per book ..............

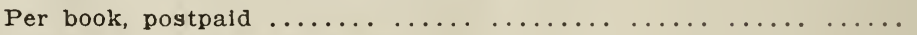

Used for setting out grafts, etc. Each ..............\$ 0 (1)

\section{GRATTITG TEREAD}

Unwaxed, per ball ............................ 10c

Waxed, per ball ............................... 12 $1 / 2 \mathrm{c}$

One ball of waxed thread will wind about 4,000 grafts. If ordered by mail add 2c por ball to the unwaxed, and $7 \mathrm{c}$ per ball to the waxed to pay postazo.

\section{TWIYES}

Endding-Wostenholm's I. X. I.; ivory tip; best on the market

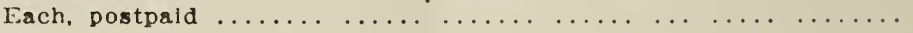

Grafting-The best all around, reasonable priced grafting knife that we know of. Hare used them in our own grafting room, anil wold thom to the trade for years, and they give excellent atisfac-

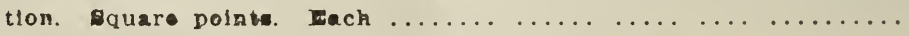

\section{IAIBIES}

W. earry conatantly on hand a lars stoek of labela, which ar put up in neet packares of 1,000 each, all ready for use. They are of a uperior quallty and will pleave.

Notehed, iron wired, y inch, plain. Per $1,000 \ldots \ldots \ldots$....... 750

Notohed copper wired, s 1 ineh, plain. Por $1,000 \ldots \ldots \ldots \ldots$. . . 100.

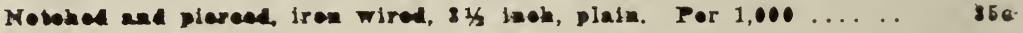




\section{NURSERYMEN'S SUPFIIES (Continued)}

\section{IABEL WIRE (Iron.)}

Cut ready for use. Per pound ...................... 20c

Per pound, postpaid ........................... $36 \mathrm{c}$

\section{MUIE SRIN MITTENS}

Made out of mule skin. Very durable and wear like buck skin. Just the thing to handle trees, roses, etc. We carry in stock both the gloves and mittens. In the mitten there are two sheaths- one for the forefinger and one for the other three fingers. Each ...... Per dozen ....................................

\section{NEEDIES.}

For sewing burlap; 6 -inch curved; best. Per dozen...........

\section{ORDER BOOKS}

Contain 25 order sheets; also duplicates, which are of different color. Our name does not appear on these blanks. Each ...........

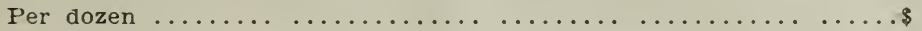

\section{PAPER}

To line boxes to protect contents from wind, frost, etc. We buy same in carload lots, and it comes in rolls weighing from 60 to 65 pounds; 33 inches wide. You will find this paper of good quality.

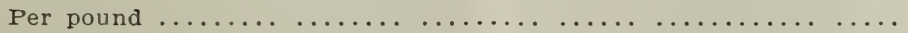

\section{PRUNING SHEARS}

California pattern, 9 inches; plain nut, steel blades, blued; flat steel

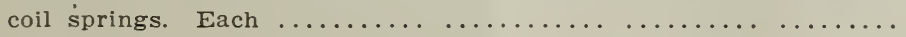

\section{RAFIA}

Fresh stock, "Red Star Brand." Per pound ...............

\section{SHINGIE-TOW}

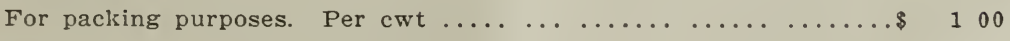

\section{SPADES}

Ames make; the best nirsery spade; strapped full length of handle, both back and front, with steel straps. Each ........\$

\section{TWINES}

Sewing Twine for burlapping; pure flax; spun special process; in skeins. Per pound ............................

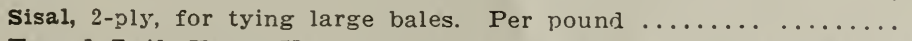

Tarred Iath Yarn-Used for tying trees in bunches. We use $12 \mathrm{c}$ this twine especially on trees that are going into storage over winter as it does not rot like wool twine. We have it in balls of 6 pounds each. Per pound ...................... $121 / 2 \mathrm{c}$ Wool Twine-4-ply, for tying trees in bunches; put us in balls of about 1 pound each. Per pound .................... 


\section{General Index.}

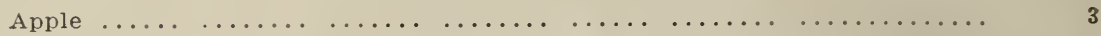

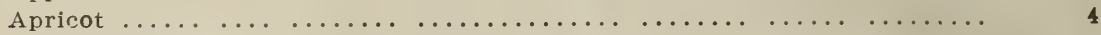

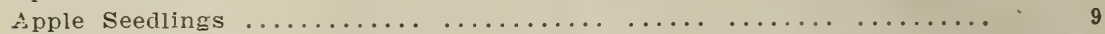

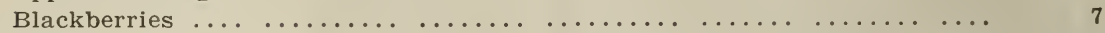

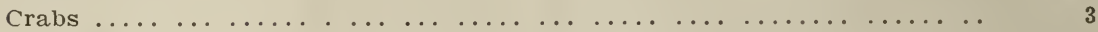

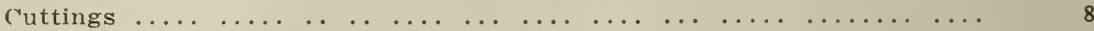

Cherries ....................................... $\ldots$

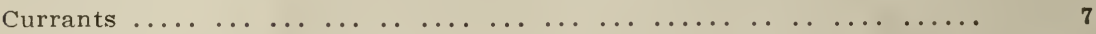

Dewberries .................................... . . . . . . . . . . . .

Deciduous Ornamental Trees .......................... . . . . 112-13

Evergreens $\ldots \ldots \ldots \ldots \ldots \ldots \ldots \ldots \ldots \ldots \ldots$

Fruit Tree Stocks ... .............................. . . . . . . . 9

Forest Tree Seedlings ... ............................ . . . . . . . . 10

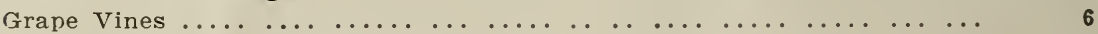

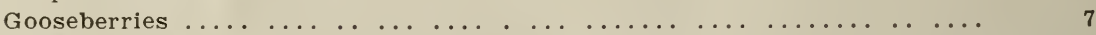

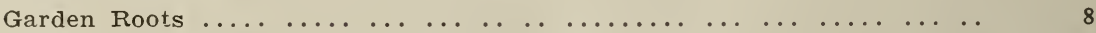

General Information .................................

H. B. Cranberries $\ldots \ldots \ldots \ldots \ldots \ldots \ldots \ldots \ldots \ldots \ldots \ldots \ldots \ldots \ldots \ldots$

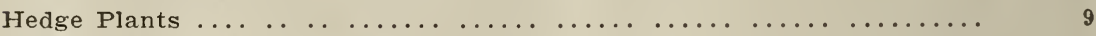

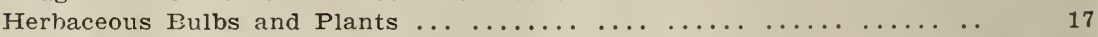

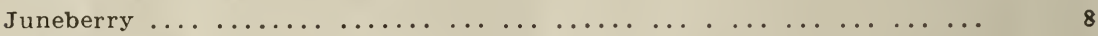

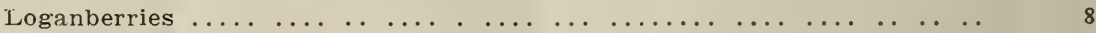

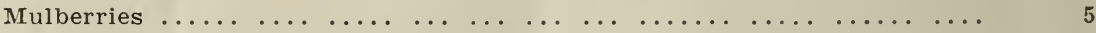

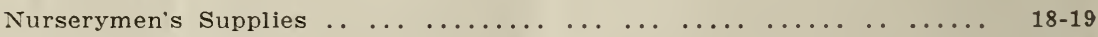

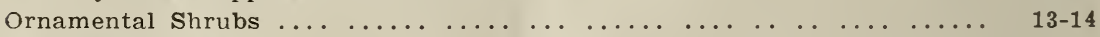

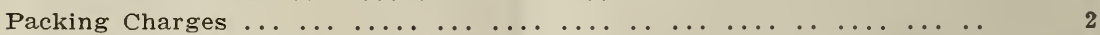

Pears, Standard, Dwarf ............................. . . . . . 4

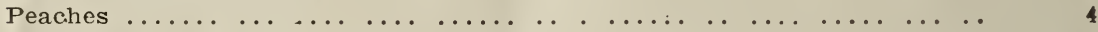

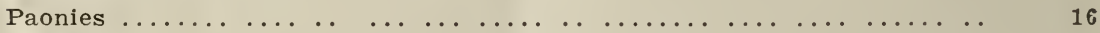

Plums ..................................... . . . . . . . . . . . 5

Quinces ....................................... . . . . . . . . . 4

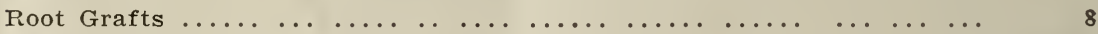

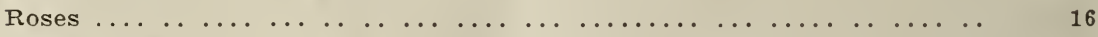

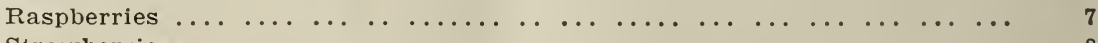

Strawberries .................................... . . . . . . . . . . 8

Tree Seeds........... $\quad \ldots \ldots \ldots \ldots \ldots \ldots \ldots \ldots \ldots$

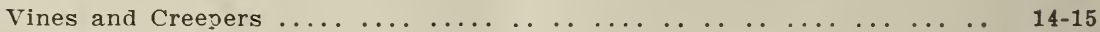

Weeping Trees ...................................... . . . . . . 10

Wineberries $\ldots \ldots \ldots \ldots \ldots \ldots \ldots \ldots$

STATE OF IOWA

CERTIFICATE OF NURSERY INSPECTION

Office of State Eneomologist, Ames, Iowa

This is to Certify, That in accordance with Chapter 53 of the Acts of the Twenty-seventh General Assembly, as amended by the Thirty-first General Assembly, the nursery stock for sale by The Shenandoah Nurseries, D. S. Lake, Propr., of Shenandoah, Iowa, has been inspected by a duly authorized inspector and has been found apparently free from dangerusly injurius insects and plant diseases.

Certificate No. 31.

This certificate is invalid after July $1,1907$.

Dated, July 21, 1906.

H. E. SUMMERS,

State Entomologist. 